\title{
The effect of the formulation of kenikir leaf extract (Cosmos caudatus) and blimbing wuluh extract (Averrhoa bilimbi) on the functional drink quality
}

\author{
S.C. Batubara ${ }^{1}$, F. Nurkolis ${ }^{2}$ and A.A. Putri ${ }^{1}$ \\ ${ }^{1}$ Department of Food Sciences and Technology, Faculty of Food Technology and Health, Sahid University of Jakarta, \\ South Jakarta, Indonesia and \\ ${ }^{2}$ Department of Biological Sciences, Faculty of Sciences and Technology, State Islamic University of Sunan Kalijaga, \\ Yogyakarta, Indonesia
}

Kenikir is widely used as a herbal medicine in Southeast Asia especially Indonesia and has been reported as a rich source of bioactive compounds such as ascorbic acid, quercetin, and chlorogenic acid ${ }^{(1)}$. Belimbing wuluh widely used in the treatment of diabetes mellitus, hypertension, and as an herbal antimicrobial agent ${ }^{(2)}$. Therefore, both of them have the potential to be developed into functional drinks. This study was aimed to obtain the effect of the formulation of kenikir leaf extract and blimbing wuluh extract on the functional drink quality specially in antioxidant.

This study was an experimental research used was a completely randomized design one factor consisting of five treatments (30:70, 40:60, 50:50, 60:40, 70:30) with three replications. The Functional drink quality determined by chemical tests ( $\mathrm{pH}$ and total dissolved solid), organoleptic tests (hedonic and hedonic quality in colour, aroma, and taste). Antioxidant activity test will be done to the best functional drink quality. The Organoleptic test was running by 30 panellists. Data were analyzed by analysis of variance (ANOVA) at $95 \%$ confidence level, if there is significant effect then continued with Duncan's to find out the differences between treatments.

The results showed that the best functional drink formulation obtained by formulating kenikir leaf extract and belimbing wuluh extract at 40:60. This formulation has characteristic $\mathrm{pH} 3.97$, total dissolved solid 20.23 o Brix, the hedonic average value with the colour parameter is 3.6 (like-really like), the hedonic average value with aroma parameters is 3.4 (likes), the hedonic average value with the taste parameter is 3.3 (like), the average value hedonic quality with colour parameters namely 3.3 (green), the average value of quality hedonic with aroma parameters, namely 3,4 (rather strong), and the average value of quality hedonic with taste parameters namely 4.6 (slightly sour sweet - sweet sour). The results of antioxidant testing with the DPPH method on functional drinks 40:60 formulation showed as much as $48.21 \%$ antioxidant activity.

Based on the research results, it is suggested to make functional drink using kenikir leaf extract and belimbing wuluh extract 40:60 formulations. However, however, the formulation found sedimentation which could affect the quality of the drink

\section{Acknowledgements}

We thank Sahid University and all of respondends for their outstanding help in formatting the original communications.

\section{References}

1. Cheng SH, Barakatun-Nisak MY, Anthony J, et al. (2015) J Res Med Sci 20(10), 1000-6.

2. Alhassan AM \& Ahmed QU (2016) J Pharm Bioallied Sci 8(4):265-271. 